\section{Nauplius}

The JOURnAL OF The

Brazilian Crustacean Society

e-ISSN 2358-2936

www.scielo.br/nau www.crustacea.org.br

\title{
First record of Grapsus grapsus (Linnaeus, 1758) (Brachyura: Decapoda: Grapsidae) in freshwater habitat
}

\author{
Tammy Iwasa Arai ${ }^{1}$ (D) orcid.org/0000-0002-3654-8671 \\ Manoela Costa Brandão ${ }^{2}$ \\ Andrea Santarosa Freire ${ }^{2}$ (D) orcid.org/0000-0001-6280-7254
}
1 Laboratório de Carcinologia, Departamento de Invertebrados, Museu Nacional/ UFRJ. 20940-040, Rio de Janeiro, Rio de Janeiro, Brazil.
TIA E-mail: araitammy@gmail.com
2 Laboratório de Crustáceos/Plâncton, Departamento de Ecologia e Zoologia, CCB/
UFSC, Campus Universitário Trindade. 88010-970 Florianópolis, Santa Catarina,
Brazil.
MCB E-mail: manoelacb@yahoo.com.br
ASF E-mail: andrea.freire@ufsc.br

ZOOBANK http://zoobank.org/urn:lsid:zoobank.org:pub:CCFA62B2-AE42-42C7-

B310-E2F6CE49B6D5

\section{Abstract}

The sally lightfoot crab, Grapsus grapsus (Linnaeus, 1758), has been recorded from the oceanic islands off Brazil, as well as from the Caribbean, in coastal rocky shores in the Eastern Pacific, and in Galapagos. We report the first observation of G. grapsus in freshwater habitat, registered in a stream at Trindade Island, Brazil.

\section{KEY WORDS}

Trindade Island, Grapsoidea, salinity, inland, South Atlantic Ocean.

The family Grapsidae MacLeay, 1838 is comprised by 10 genera and 41 extant species (De Grave et al., 2009), represented by coastal, oceanic and estuarine crabs. Species of the family Grapsidae are known to inhabit especially rocky shores and mangroves, tolerating a wide range of salinities, such as the mangrove root crab Goniopsis cruentata (Latreille, 1803) (Martelo and Zanders, 1986) and the mottled shore crab Pachygrapsus transversus (Gibbes, 1850) (Warburg et al., 1987), found in Brazilian mangroves and rocky shores.

The genus Grapsus Lamarck, 1801 currently comprises eight valid species CORRESPONDING AUTHOR Andrea Santarosa Freire andrea.freire@ufsc.br

SUBMITTED 27 February 2017 ACCEPTED 9 September 2017 PUBLISHED 4 December 2017

DOI 10.1590/2358-2936e2017032 (Davie and Türkay, 2011), widespread around the world (Schubart, 2011). The only species recorded in American waters is the sally lightfoot crab Grapsus grapsus (Linnaeus, 1758). In Brazil, G. grapsus is restricted to rocky shores of the oceanic islands of Fernando de Noronha, Rocas' Atoll, St. Paul's Rocks and Trindade (Freire et al., 2011; Teschima et al., 2016). 
It is also found in the Caribbean, along the tropical Pacific coasts of Central and South America and Galapagos Islands (Teschima et al., 2016).

The island of Trindade is located at the eastern limit of the Vitória-Trindade submarine Ridge (20³0'S $29^{\circ} 20^{\prime} \mathrm{W}$ ), in southeastern Brazil. It forms the easternmost group of islands off Brazil, together with the Martin Vaz Archipelago, which lies $48 \mathrm{~km}$ east of Trindade (Fig. 1A). Trindade Island hosts one unique population of G. grapsus that is genetically distinct from the population of the other three equatorial islands (Teschima et al., 2016). The species has been recorded from the rocky shores of 'Praia das Tartarugas' and 'Pão de Açúcar' since the first scientific expedition to the island (Oliveira, 1951). In this study we report for the first time the occurrence of G. grapsus in freshwater habitat.
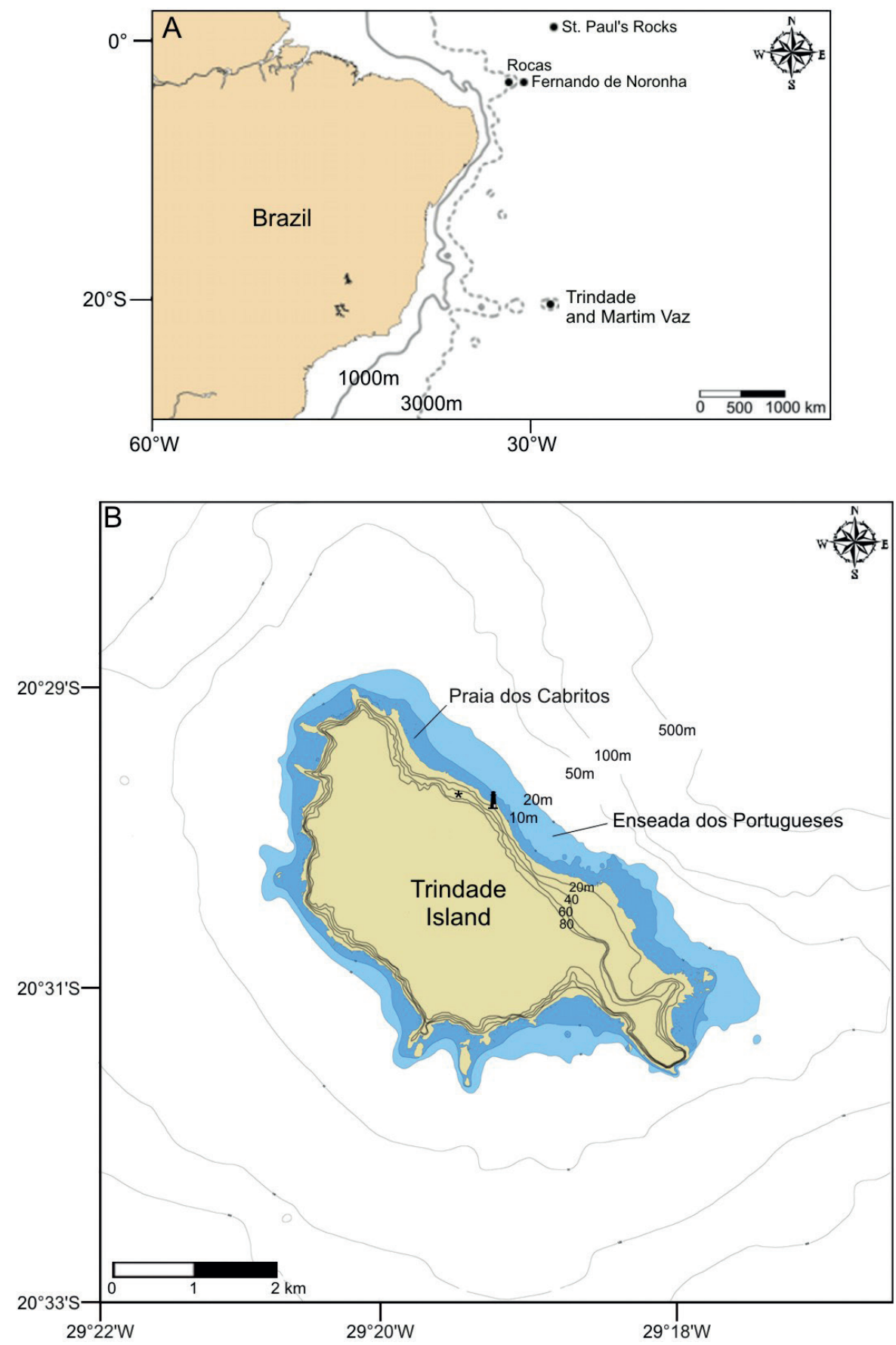

Figure 1. A, Location of the Brazilian oceanic islands, including Trindade Island; B, map of Trindade Island. Asterisk shows the location of the freshwater stream where Grapsus grapsus were found. Lighthouse corresponds to Ponta do Valado. 
Approximately 15 specimens of G. grapsus were observed in a shallow stream $50 \mathrm{~m}$ above the sea level between the 'Enseada dos Portugueses' and 'Praia dos Cabritos', $750 \mathrm{~m}$ further from the northeast coast (in a straight line) of Trindade Island (20 29'41"S $29^{\circ} 19^{\prime} 32^{\prime} \mathrm{W}$ ) on May 27th 2015 (Figs. 1B, 2A, B). The stream was about $30 \mathrm{~cm}$ deep in a small bank (one meter wide) on the top of the hill and the water flowed in sweeping meanders $(10 \mathrm{~cm}$ deep) between and on the top of the rocks, towards a steady but also winding waterfall over the steep slope. According to local rangers, the crabs always inhabit this permanent stream. The crabs were mostly crossing the stream over the rocks, eventually walking into the water, hidden below the rocks, with part of their bodies underwater. One crab was totally submerged with a thin water layer covering its body, and it stood practically immobile inside the water for approximately 10 minutes during our presence. Otherwise, the crabs were not seen submerged, which is reasonable since also in the marine environment they are rarely observed under water, but close to shallow tide pools (ASF, pers. observ.). There was no evidence of a downward movement towards the splash zone. The G. grapsus observed in the stream had different colour patterns, ranging from the small green ones to partially red (Fig. 2C-E). Partially red males are functionally mature and green males have not yet gone through the puberty molt, while it is possible to encounter green females that are sexually mature (Freire et al., 2011). Therefore the population includes sexually matured specimens, especially females. Fully red larger crabs were not registered in the freshwater stream. A thin and irregular water flow was observed upon the rocky coast at sea level. The crabs were randomly occupying the rocks at the sea level up to the steep slope. The specimens found in fresh water were morphologically identical to the specimens from the rocky shore, suggesting that the rocky shore crabs moved progressively upwards trespassing the vegetation and rough soil to establish in the main freshwater stream. In the freshwater stream, G. grapsus were seen sharing the habitat with the gecarcinid crab Johngarthia lagostoma (H. Milne Edwards, 1837). These species usually shared the rocky flat area during the

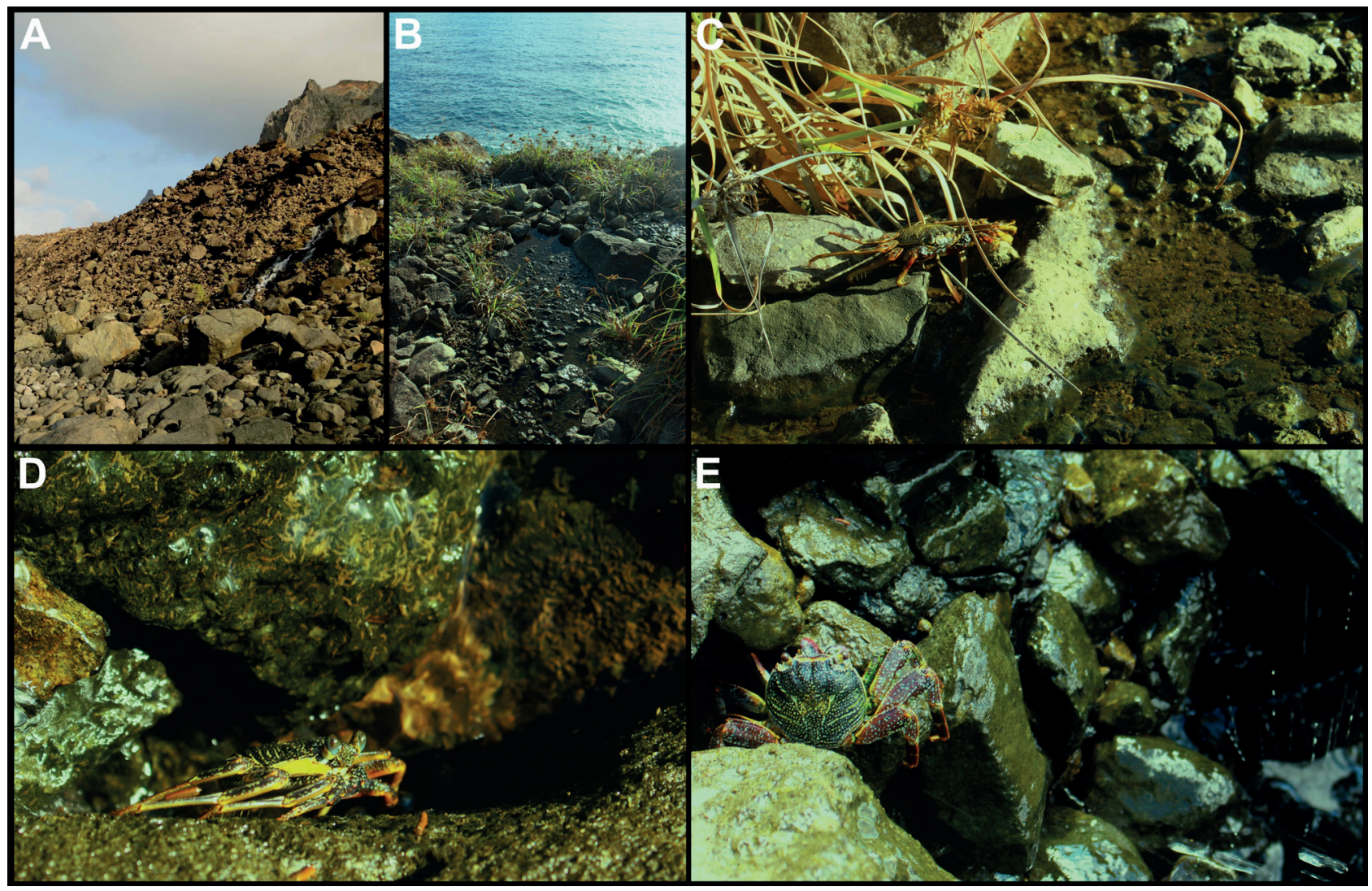

Figure 2. Freshwater stream inhabited by Grapsus grapsus. A, Downward flow to the rocky coast (photo credit: Hilton Entringer); B, main freshwater stream uphill; C-E, G. grapsus in the freshwater stream at Trindade Island. 
night in Trindade Island, when J. lagostoma moved to the sea level. Considering the four Brazilian oceanic islands, there is no fresh water in Rocas' Atol and Saint Paul's rocks. There are no records of G. grapsus frequenting freshwater sites in Fernando de Noronha, probably because there are few freshwater streams in Fernando de Noronha, which remains dry during most of the year (Eston et al., 1986). This is the first record of G. grapsus in a freshwater habitat despite its wide neotropical distribution. Although all other species of the genus were only recorded in marine environments, this record corroborates the salinity tolerance already observed in other Grapsoidea (Gittenberger et al., 2010; Seeley et al., 2015).

\section{ACKNOWLEDGEMENTS}

We are thankful to Hilton Entringer (Tamar) and Daniel Margotti (INPE), for their help during the fieldwork, Hilton Entringer also provided the picture of the stream. PROTRINDADE/SECIRM and the N.Ap.Oc. Ary Rongel crew for the logistical support. This work was supported by the CNPq research grant 484875/2012-4. ASF also benefited from a CNPq grant (312644/2013-2). TIA was supported by a MSc scholarship from CNPq, and MCB by a PhD scholarship from CAPES.

\section{References}

Davie, P. and Türkay, M. 2011. Grapsus Lamarck, 1801. Accessed through: World Register of Marine Species at http://www. marinespecies.org/aphia.php? $\mathrm{p}=$ taxdetailsandid $=106963$ on 2017-02-09

De Grave, S.; Pentcheff, N.D.; Ahyong, S.T.; Chan, T.-Y.; Crandall, K.A.; Dworschak, P.C.; Felder, D.L.; Feldmann, R.M.; Fransen, C.H.J.M.; Goulding, L.Y.D.; Lemaitre, R.; Low, M.E.Y.; Martin, J.W.; Ng, P.K.L.; Schweitzer, C.E.; Tan, S.H.; Tshudy, D. and Wetzer, R. 2009. A classification of living and fossil genera of decapod crustaceans. Raffles Bulletin of Zoology, Supplement 21: 1-109.

Eston, V.R.D.; Migotto, A.E.; Oliveira Filho, E.C.D.; Rodrigues, S.D.A.; and Freitas, J.C.D. 1986. Vertical distribution of benthic marine organisms on rocky coasts of the Fernando de Noronha Archipelago (Brazil). Boletim do Instituto Oceanográfico, 34: 37-53.

Freire, A.S.; Pinheiro, M.A.A.; Karam-Silva, H. and Teschima, M.M. 2011. Biology of Grapsus grapsus (Linnaeus, 1758) (Brachyura, Grapsidae) in the Saint Peter and Saint Paul Archipelago, Equatorial Atlantic Ocean. Helgoland Marine Research, 65: 263-273.

Gittenberger, A.; Rensing, M.; Stegenga, H. and Hoeksema B. 2010. Native and nonnative species of hard substrata in the
Dutch Wadden Sea. Nederlandse Faunistische Mededelingen, 33: 21-76.

Lamarck, J.B.P.A.M. 1801. Systême des animaux sans vertèbres; ou, Tableau général des classes, des classes, des orres et des genres de ces animaux. Paris, Deterville, 432p.

Latreille, P.A. 1803. Histoire naturelle, générale et particulière des crustacés et des insectes: ouvrage faisant suite aux oeuvres de Leclerc de Buffon, et partie du cours complet d'histoire naturelle rédigé par C. S. Sonnini / par P. A. Latreille. Paris, F. Dufarte, 394p

Linnaeus, C. 1758. Systema naturae per regna tria naturae, secundum classes, ordines, genera, species, cum characteribus, differentiis, synonymis, locis. $10^{\text {th }}$ ed., v. 1,824 p.

MacLeay, W.S. 1838. On the brachyurous decapod Crustacea brought from the Cape by Dr. Smith. p. 53-71. In: A. Smith (ed), Illustrations of the Annulosa of South Africa; being a Portion of the Objects of Natural History Chiefly Collected during an Expedition into the Interior of South Africa, under the Direction of Dr. Andrew Smith, in the Years 1834, 1835, and 1836; fitted out by "The Cape of Good Hope Association for Exploring Central Africa": together with a summary of African Zoology, and an inquiry into the geographical ranges of species in that quarter of the globe. London, Smith, Elder \& Co.

Martelo, M-J. and Zanders, P. 1986. Modifications of gill ultrastructure and ionic composition in the crab Goniopsis cruentata acclimated to various salinities. Comparative Biochemistry and Physiology, Part A: Physiology, 84: 383-389.

Milne Edwards, H. 1837. Histoire naturelle des Crustacés, comprenant l'anatomie, la physiologie et la classification de ces animaux, 2: 1-532.

Oliveira, L.P.H. 1951. Nota prévia sobre a fauna e flora marinha bentônica da Ilha da Trindade. Memórias do Instituto Oswaldo Cruz, 49: 443-456.

Pinheiro, M.A.A.; Santana, W.; Bezerra, L.E.A.; Kriegler, N. and Rio, J.P.P. 2016. Avaliação dos Caranguejos Grapsídeos (Decapoda: Grapsidae).p. 182-191. In: M.A.A. Pinheiro and H. Boos (orgs), Livro Vermelho dos Crustáceos do Brasil: Avaliação 2010-2014, Cap. 14. Porto Alegre, Rio Grande do Sul, Sociedade Brasileira de Carcinologia.

Schubart, C.D. 2011. Reconstruction of phylogenetic relationships within Grapsidae (Crustacea: Brachyura) and comparison of trans-isthmian versus amphi-atlantic gene flow based on mtDNA. Zoologischer Anzeiger, 250: 472-478.

Seeley, B.; Sewell, J. and Clark, P.F. 2015. First GB records of the invasive Asian shore crab, Hemigrapsus sanguineus from Glamorgan, Wales and Kent, England. Marine Biodiversity Records, 8: e102. doi: 10.1017/S1755267215000809

Teschima, M.M.; Stroher, P.R.; Firkowski, C.R.; Pie, M.R. and Freire, A.S. 2016. Large-scale connectivity of Grapsus grapsus (Decapoda) in the Southwestern Atlantic oceanic islands: integrating genetic and morphometric data. Marine Ecology, 37: $1360-1372$.

Warburg, M.R.; Goldenberg, S. and Tudiver, B. 1987. Osmotic and ionic regulation in two Pachygrapsus crabs, under varying salinities and dehydration. Comparative Biochemistry and Physiology Part A: Physiology, 86: 761-765. 